Pak. J. Agri., Agril. Engg., Vet. Sci., 2021, 37 (1): 29-35

ISSN: 1023-1072 (Print), ISSN: 2663-7863 (Online)

https://doi.org/10.47432/2020.37.1.4

\title{
EFFECTS OF RAINWATER HARVESTING ON YIELD OF WHEAT AND MAIZE CROPS IN PAKISTAN
}

\author{
I. Jan ${ }^{* 1}$, S. Khan ${ }^{1}$ and T. Mahmood ${ }^{2}$ \\ ${ }^{1}$ Institute of Development Studies (IDS), University of Agriculture, Peshawar, Pakistan \\ ${ }^{2}$ Department of Rural Development, Karakorum International University, \\ Daimir-Chilas Campus, Gilgit-Baltistan, Pakistan
}

\begin{abstract}
This paper attempts to identify the effect of rainwater harvesting $(\mathrm{RWH})$ and rainfed irrigation on yield of wheat and maize crops in Pakistan. The study was carried out in two villages, namely, Reerh and Ghoutar of district Mansehra, Khyber Pakhtunkhwa, Pakistan. A total of 200 farming households were randomly selected from both villages. A questionnaire survey was conducted to collect primary data. The descriptive analysis shows that farmers in the research area had adopted small-scale, indigenous RWH schemes such as channels, bunds, tanks, and rooftop collection. A paired-samples t-test was used to compare the yield of wheat and maize crops between irrigated and rainfed farming systems. The results of the paired t-test confirmed a difference in yield of wheat and maize in irrigated and rainfed conditions. The study concludes that the large portion of uncultivated land could be cultivated if water shortage problem is resolved through the promotion of community-led RWH schemes in the area. This will help in sustainable agricultural development in the area.
\end{abstract}

Keywords: crop water requirement, monsoon rains, rainfed irrigation, rainwater harvesting, crop yield

\section{INTRODUCTION}

Agriculture sector is the largest single consumer of all water resources taken together, i.e., rainfall (referred to as green water) and water in rivers, lakes and aquifers (referred to as blue water) (Oweis and Hachum, 2009). On average, agriculture accounts for 70 percent of the global freshwater (FAO, 2017). However, water availability for agriculture is expected to be decreased in the near future (Jan, 2020a). The situation will be exacerbated by the climate change which will result in declines in rainfall and amplification of extreme events (Tabari, 2020). This emphasizes the need for water management in rainfed agriculture to store water required for food production (Rockström et al., 2010). Literature shows that agricultural productivity worldwide is lower in rainfed areas than irrigated farming systems. The productivity remains low due to decreased optimal rainfall features, unfavorable land conditions and lack of appropriate management of these resources (Helmreich and Horn, 2009). In developing countries, average grain yield in rainfed agriculture is 1.5 tons per hectare as compared

"Corresponding author: inayat43@aup.edu.pk to 3.1 tons per hectare in irrigated agriculture (Rosegrant et al., 2002). This implies that low yields in rainfed agriculture in developing countries can be increased with proper water management and conservation practices (Baig et al., 2013).

Pakistan's population is growing at a faster rate. The present population of the country is 224.25 million (Worldometer, 2021). By the year 2030, the population of Pakistan will reach to 262.59 million (UN, 2019). Food security for this burgeoning population is a major challenge facing Pakistan. To meet water requirements for the agricultural lands is a widely recognized means to increase food production per unit area. Sustainable agricultural development does not only mean to provide food for the rising population but also saves water for future uses (FAO, 2015). The challenge is to develop and apply environmental friendly water-saving techniques and management methods, particularly, in the water scarce areas. One of the potential water scarce areas in Pakistan is the mountain ranges where agriculture is mostly rainfed and a large number of farmers merely grow for survival.

Pakistan has two mountain ranges in the Hindu Kush-Himalayas namely the western 
mountains and the northern mountains. Western mountains include major part of Kohat and Bannu Districts of Khyber Pakhtunkhwa (KP) and tribal areas of Kurram, North Waziristan, South Waziristan, Bannu and Kohat. Northern mountains include Malakand Division, Hazara Division, Northern Areas and Murree-Kahuta Tehsil of Rawalpindi District (Jan, 2020b). This research was carried out in the northern mountains of $\mathrm{KP}$. In the research area, agriculture is rainfed and farmers use indigenous $\mathrm{RWH}$ schemes to irrigate fields during different cropping stages.

The current research makes an attempt to answer the following important questions: 1) What are the particular type of small-scale, indigenously developed RWH schemes (with low water storage capacity) that farmers uptake? 2) What is the role of efficient use of harvested water in increased production of the major grain crops in the research area?

The paper contributes to literature on RWH exemplifying Pakistan. The study addresses the gap that no empirical evidence exists on the yield difference between irrigated and rainfed farming systems in Pakistan. The novelty of the paper is that it takes into account the smallscale; indigenously developed RWH schemes compared to the formally developed schemes having larger efficiency. The paper also compares the yield of different crops cultivated in both rainfed and irrigated conditions.

\section{MATERIALS AND METHODS}

The research was carried out in District Mansehra of Khyber Pakhtunkhwa Province in
Pakistan (Figure 1) from June to September, 2014. Situated at $216 \mathrm{~km}$ from Peshawar, Mansehra has a hilly terrain and agriculture uphill is mostly rainfed. Like other mountain ranges of the Himalayan region, Mansehra has an unpredictable weather with poor and unevenly distributed rainfall. Most of the arable land is rainfed and scarcity of rains after monsoons results in drought like situation. To overcome water shortage problem, farmers have developed indigenous small-scale RWH schemes in the area.

Two villages namely Reerh and Ghoutar were selected as a sample. The villages were selected because of the large number of indigenously developed small-scale RWH schemes (Jan, 2020a). The total number of households in Reerh and Ghouter were 350 and 300 respectively. There were two types of farmers in these villages: those who have taken up the existing schemes and those who had not. A total of 50 respondents were randomly selected from each category in both villages using an equal allocation and simple random sampling techniques. Thus, the total sample size was 200 farming households. A semi-structured questionnaire was used to collect primary data from the male farming head of the household. The questionnaire was pre-tested in the field and necessary changes were made before starting the main field survey. A paired-samples t-test was conducted to compare the yield of wheat and maize crops in irrigated and rainfed farming systems.

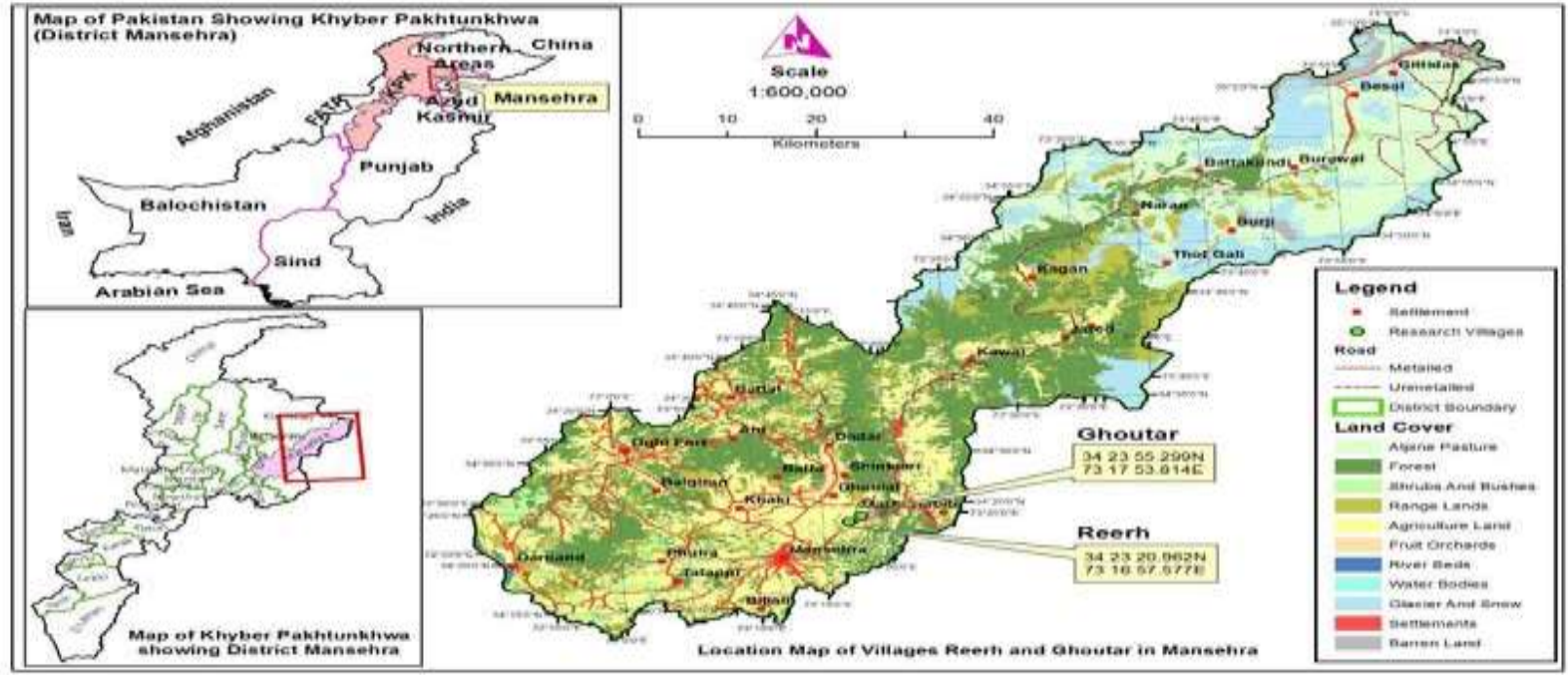

Figure 1. Map of Pakistan showing the research villages 
Let $\mathrm{d}=$ difference between yield of crops grown on irrigated and rainfed land, then paired t-test tests the following hypotheses:

$\mathrm{H}_{0}: \mu \mathrm{d}=0$

$\mathrm{H}_{1}: \mu \mathrm{d} \neq 0$

To test the null hypothesis $\left(\mathrm{H}_{0}\right)$, a pairedsamples t-test is used, which is:

$$
t=\frac{\bar{d}}{S . E(d)}
$$

Where $d$ denotes the mean of differences in yield and S.E(d) is the standard error of differences in yield between irrigated and rainfed farming systems.

\section{RESULTS AND DISCUSSION Uptake of indigenous RWH schemes}

As mentioned earlier, small-scale RWH schemes already existed in the research villages. The schemes were mostly constructed indigenously with minimal efficiency. It was noted that farmers had adopted RWH systems such as channels, bunds, tanks, and rooftop collection. Figure 2 provides information about the existence of different indigenously built RWH schemes and the proportion of sample population that had adopted it (Jan, 2020b).

The figure explains that 50 percent respondents in both villages were using no $\mathrm{RWH}$ scheme at all. The remaining 50 percent in each village were the adopters of the schemes. The figure shows that 16 percent in Reerh and 18 percent in Ghoutar were using RWH channels to store water for irrigation purposes. Another 10 percent in Reerh and 12 percent in Ghoutar had constructed bunds as water storage reservoirs. These two types of techniques require a minimal technical know-how and finances. However, the water storage capacity and longevity is too small. It was also observed that 10 percent respondents in Reerh had constructed water tanks for storing water. Another 12 percent were collecting rainwater in ponds which either they had constructed by their own or naturally existed. Similarly, 8 percent and 10 percent in Ghoutar were also collecting rainwater through tanks and ponds respectively. A very common RWH technique - the rooftop collection - was however, adopted by only 2 percent respondents in both villages respectively.

\section{RWH and crop productivity}

Agriculture is highly linked to food security, nutrition, health, and the environment and is a major driver to attain the sustainable development goals (SDGs) (FAO, 2017). Improving agricultural productivity, while conserving water, is an essential requirement for farmers to increase global food supplies on a sustainable basis. That is why the role of $\mathrm{RWH}$ in improving productivity in rainfed agriculture has been appraised by previous research (Ali et al., 2007). Globally, rainfed agriculture is the primary source of food production (FAO, 2017). In Pakistan, few selected crops such as wheat, rice, cotton, sugarcane, and maize dominate the overall crop production (Abbas, 2013; GoP 2019). However, it has been noted that productivity of cereals, particularly summer crops, is too low in Pakistan (Ahmad et al., 2016). In the research area, the major grains crops were wheat and maize. Besides, rice and vegetables were also grown on small piece of land. The area under the major crops (wheat and maize) and per unit yield is discussed below.

\section{Area under wheat and yield per unit area}

Wheat (Triticum aestivum L.) is one of the most valuable crops and a staple food for the vast majority of the human population. Wheat is cultivated under a wide range of moisture conditions where precipitation ranges from 250 to $1750 \mathrm{~mm}$ (Tiryakioğlu et al., 2015). Like other countries, wheat is the major crop in Pakistan and is sown on both irrigated and rainfed lands. The share of wheat in national GDP is 2.2 percent and the crop contributes 10.1 percent to value added agriculture (Hussain et al., 2014). In brief, the crop has a dominant position in the formulation of agriculture sector policies in the country (GoP, 2020). Yet, yield levels in the rainfed areas of Pakistan are exceptionally low, which can be increased if special attention is given to agricultural development in these areas (Abbas, 2013). Because of unavailability of water, farmers in the research villages grow wheat on a small proportion of land merely for their own consumption. Table 1 explains the area under wheat crop, yield, and differences in yield in both irrigated and rainfed situations in the villages.

The results show that the average irrigated area under wheat crop in village Reerh was 5.48 kanals and rainfed area was 19.79 kanals. The production in case of irrigated and rainfed was $291 \mathrm{~kg} / \mathrm{kanal}$ and $205 \mathrm{~kg} / \mathrm{kanal}$, respectively. 

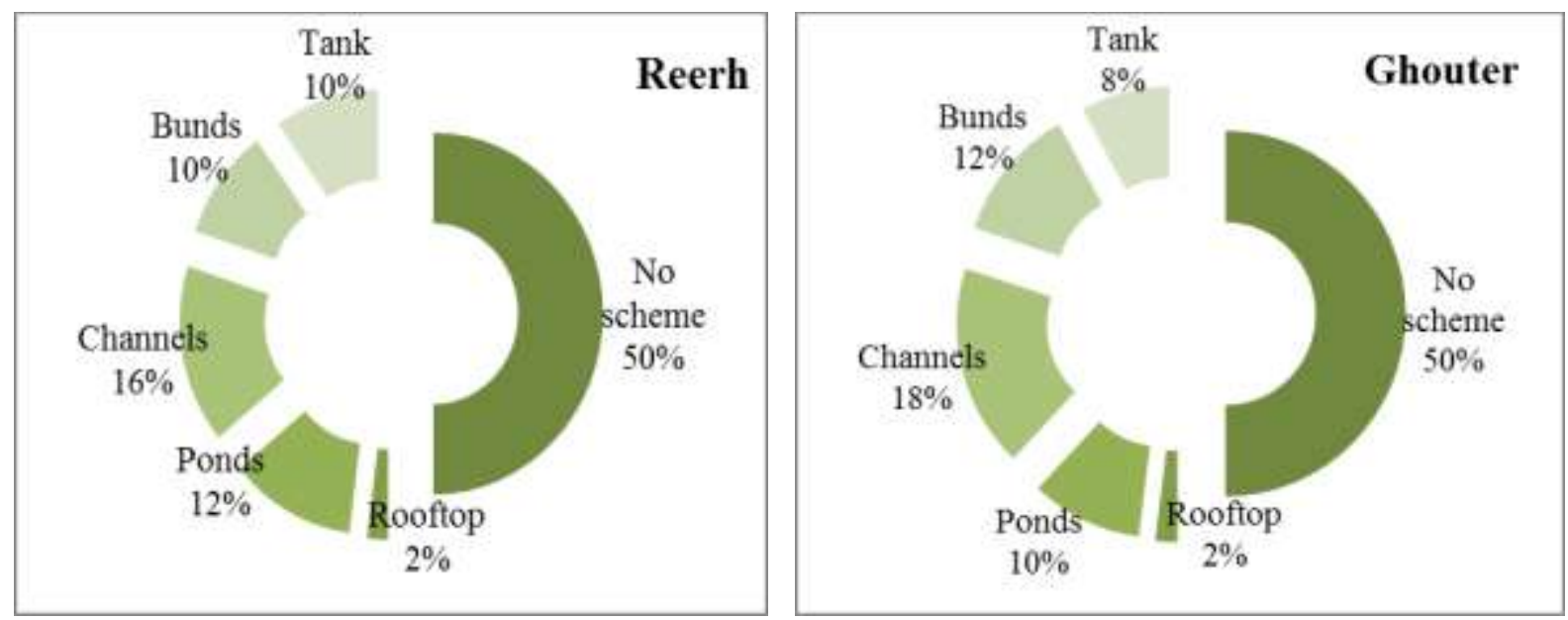

Figure 2. Uptake of indigenous RWH techniques (Source: Jan, 2020b)

Table 1. Area under wheat crop and total yield in irrigated and rainfed conditions

\begin{tabular}{|l|l|l|l|l|l|l|l|l|}
\hline Village & \multicolumn{3}{|c|}{ Irrigated (Mean values) } & \multicolumn{2}{c|}{ Rainfed (Mean values) } & $\mathrm{t}$ & $\mathrm{P}$ \\
\cline { 2 - 9 } & $\begin{array}{l}\text { Area } \\
\text { under } \\
\text { cultivation } \\
\text { Kanal }\end{array}$ & $\begin{array}{l}\text { Total } \\
\text { yield } \\
\text { (Kanal) }\end{array}$ & $\begin{array}{l}\text { Area } \\
\text { under } \\
\text { cultivation } \\
\text { Kanal }\end{array}$ & $\begin{array}{l}\text { Total } \\
\text { yield }\end{array}$ & & \\
\hline Reerh & 5.48 & 291 & 1436 & 19.79 & 205 & 4086 & 13.41 & .000 \\
\hline$(\mathrm{N}=100)$ & & & & & & & & \\
\hline Ghoutar & 5.52 & 314 & 1803 & 17.73 & 235 & 4202 & 12.22 & .000 \\
\hline$(\mathrm{N}=100)$ & & & & & & & & \\
\hline
\end{tabular}

"Kanal is a local unit of land measurement and is used here because the farmers had very small landholding. $1 \mathrm{Kanal}$ is equal to 0.05 hectares.

Table 2. Area under maize crop and total yield in irrigated and rainfed conditions

\begin{tabular}{|c|c|c|c|c|c|c|c|c|}
\hline \multirow[t]{2}{*}{ Village } & \multicolumn{3}{|c|}{ Irrigated (Mean values) } & \multicolumn{3}{|c|}{ Rainfed (Mean values) } & \multirow[t]{2}{*}{$t$} & \multirow[t]{2}{*}{$\mathrm{P}$} \\
\hline & $\begin{array}{l}\text { Area under } \\
\text { cultivation }\end{array}$ & $\begin{array}{l}\text { Yield per } \\
\text { Kanal }\end{array}$ & $\begin{array}{l}\text { Total } \\
\text { yield }\end{array}$ & $\begin{array}{l}\text { Area } \\
\text { under } \\
\text { cultivation }\end{array}$ & $\begin{array}{l}\text { Yield per } \\
\text { Kanal }\end{array}$ & $\begin{array}{l}\text { Total } \\
\text { yield }\end{array}$ & & \\
\hline & $($ Kanal)* & & $(\mathrm{Kg})$ & (Kanal) & & $(\mathrm{Kg})$ & & \\
\hline Reerh & 5.31 & 261 & 1315 & 14.63 & 180 & 2568 & 4.13 & .000 \\
\hline$(\mathrm{N}=100)$ & & & & & & & & \\
\hline Ghoutar & 9.10 & 345 & 3000 & 17.43 & 184 & 2997 & 21.73 & 000 \\
\hline$(\mathrm{N}=100)$ & & & & & & & & \\
\hline
\end{tabular}

The results of a paired-samples t-test indicate that there is a highly significant difference between the yield in irrigated and rainfed conditions, as shown by the t-value of 13.41 and $p$-value of .000 (highly significant). This implies that the average per unit yield in irrigated conditions is significantly higher than that of rainfed conditions.

Wheat plays as an important role in Pakistan's food security and hence this low area under cultivation and low yield per unit area raises serious concerns at the government level (GoP, 2020). However, this yield gap can be minimized if, among others, proper water management practices are adopted. Similarly, in village Ghoutar, wheat was sown on an average 5.52 kanals on irrigated land and 17.73 kanals on rainfed land. The production in this village was $314 \mathrm{~kg} / \mathrm{kanal}$ on irrigated land and 235 $\mathrm{kg} / \mathrm{kanal}$ on rainfed land. These results also show that there is a significant difference in the yield for irrigated $(M=314, S D=33.14)$ and 
rainfed conditions $(M=235, S D=36.01)$; $t=12.22$, and $p=.000$. These results suggest that the average per unit yield in irrigated conditions is significantly higher than that of the rainfed conditions.

Although, there are significantly higher differences in yield, the above results explain a poor yield in both irrigated and rainfed circumstances. Studies show that farmers obtain an average 30 to 60 percent less yield of major crops than their demonstrated potential in the research stations (Hussain et al., 2014). Thus per unit yield - and the resultant overall production- in both villages can be substantially increased by adopting improved farming practices. This may include bringing more area under cultivation, improved cultural practices, greater attention to tillage and harvesting, more balanced and timely use of fertilizer, and higher water-use-efficiency (Abbas, 2013).

\section{Area under maize and yield per unit area}

Maize (Zea mays L.) is another staple food crop of Pakistan and is sown on both agricultural and rainfed land. Rainfed agriculture contributes 27 percent of the maize produced in Pakistan (Baig et al., 2013). The situation of area under maize crop and the effects of availability of water on its yield, as shown in Table 2, are almost similar to that of wheat crop. The table shows that, on average, 5.31 kanals of irrigated land and 14.63 kanals on rainfed land in Reerh was under maize crop. There was also a distinct difference in yield per unit area in the village as marked by $261 \mathrm{~kg} / \mathrm{kanal}$ in case of irrigated land and 180 $\mathrm{kg} / \mathrm{kanal}$ in case of rainfed land. Similarly, the situation in village Ghoutar was not much different than village Reerh. On average, 9.10 kanals of irrigated land and 17.43 kanals of rainfed land were under maize crop. The total per unit production in Ghoutar was $345 \mathrm{~kg} / \mathrm{kanal}$ in case of irrigated land and $184 \mathrm{~kg} / \mathrm{kanal}$ in case of rainfed land. This corresponds to low yield, as the gap between maize yield at farm and research station is more than 41 percent (Hussain, 2014).

Furthermore, a paired-samples t-test was conducted to compare yield in irrigated and rainfed conditions. There was a significant difference in yields in irrigated conditions in both villages, as shown by the t-value of 4.13 and $p$ value of .000 for village Reerh, and t-value of 21.73 and $p$-value of .000 for village Ghoutar. This implies that the yield in case of irrigated conditions is significantly higher than that of rainfed conditions. Hence, the implication is that the net increase in more area under irrigation will have significant contribution in the overall production in the area.

During the field surveys, it was also reported by the sample farmers, that the land in both villages was favorable for the production of different types of vegetables and fruits. However, vegetables and fruits were grown in rare cases in both villages because of water scarcity problem.

The above discussion implies that the indigenously developed RWH techniques helped the farmers to store water and use it for irrigation purposes which resulted in increased production of wheat and maize crops. The need is, however, to develop RWH techniques in a scientific way which overcomes all the deficiencies of the indigenous RWH system. This will help in meeting crop water requirements of the farmers and will promote sustainable agriculture in the area.

\section{CONCLUSION AND RECOMMENDATIONS}

Rainwater harvesting has the potential to increase productivity of rainfed lands in Pakistan. In the research villages, farmers had developed indigenous small-scale RWH schemes such as channels, ponds, tanks, bunds, and rooftop schemes. These schemes play an important role in increasing yield of important economic crops such as wheat and maize, as demonstrated by higher per unit yield in irrigated conditions. Based on the findings of the study, it is concluded that crop production in the area can be substantially increased through proper water management in the area.

The study recommends for capitalizing on the available potential of RWH in the area by developing large-scale water harvesting schemes. For this purpose, huge amount of public and private funding needs to be allocated. Besides, the farmers should be advised (via extension services) to revisit their cropping pattern and grow drought resistant seed varieties which gives more yield. The resultant water availability will enable farmers to bring more area under cultivation during both cropping seasons which will result in increased crop production.

\section{Limitations of the study}

This study was conducted on pilot basis. Due to limited funding and time, the scope of the study was restricted to only two villages with a relatively small sample size. The study will be more rigorous if increased number of villages 
are included in the survey with large number of data units from each village. Furthermore, we studied only those villages where small-scale, indigenous RWH schemes were available. The study will provide more plausible policy implications if other villages are having formally developed large-scale RWH schemes are also included in the sample. Thus, a large scale and multi-disciplinary research on the issue under consideration is required in future.

\section{ACKNOWLEDGEMENTS}

The author is grateful to the Higher Education Commission (HEC), Pakistan for providing funding for the study. The paper is based on a book chapter published in the book 'The Kaleidoscope That is Pakistan' published by the Islamabad Policy Research Institute (IPRI), Pakistan. Part of the book chapter has been reproduced in the paper with proper permission from the editor. Thanks are extended to the editor of the book for the permission. The views explained here belong to the author and not to HEC or IPRI.

\section{AUTHOR'S CONTRIBUTION}

I. Jan: Conceptualization, literatue review, data curation and analysis, complete write up

S. Khan: Literature review, conclusion

T. Mahmood: Literature review, language editing referencing

\section{REFERENCES}

Abbas, S. 2013. Major crops of Pakistan. AgriBusiness, Punjab. http://www.agribusiness. com.pk/ major-crops-of-Pakistan.

Ahmad, S., H. Ali, U. Farooq, S. U. Khan, A. U. Rehman, N. Sarwar, A. N. Shahzad, H. Doğan, S. Hussain, M.T. Sultan and A. Waheed. 2016. Improving nitrogen-use and radiation-use efficiencies of $\mathrm{C}_{4}$ summer cereals by split nitrogen applications under an irrigated arid environment. Turkish Journal of Agriculture and Forestry, 40 (2): 280-289.

Ali, A., T. Oweis, M. Rashid, S. El-Naggar and A. A. Aal. 2007. Water harvesting options in the drylands at different spatial scales. Land Use and Water Resources Research, 7: 113.

Baig, M. B., S. A. Shahid and G. S. Straquadine. 2013. Making rainfed agriculture sustainable through environmental friendly technologies in Pakistan: A review. International Soil and Water Conservation Research, 1 (2): 36-52.
FAO, 2017. Water for sustainable food and agriculture. A report produced for the G20 Presidency of Germany. FAO, Rome. http://www.fao.org/3/i7959e/i7959e.pdf.

FAO, 2015. Towards a water and food secure future: Critical perspectives for policymakers. FAO, Rome. http://www.fao.org/ nr/water/docs/FAO_WWC_white_paper_we b.pdf).

GoP, 2020. Pakistan Economic Survey 2019-20. Ministry of Finance, Islamabad.

GoP, 2019. Economic Survey of Pakistan. Ministry of Finance, Islamabad.

Helmreich, B. and H. Horn. 2009. Opportunities in rainwater harvesting. Desalinate, 248 (1-3): 118-124.

Hussain, A. 2014. An analysis of technical efficiency of wheat farmers in Punjab. Unpublished Ph.D. Thesis. Department of Economics and Agric. Economics. PMAS Arid Agriculture University, Rawalpindi: Pakistan.

Hussain, A., M.A. Khalid, and N. Badar. 2014. Yield gap determinants for wheat production in major irrigated cropping zones of Punjab, Pakistan. Pakistan Journal of Agricultural Research, 27 (3): 188-199.

Jan, I. 2020a. Socio-economic determinants of farmers' adoption of rainwater harvesting systems in semi-arid regions of Pakistan. Journal of Agricultural Science and Technology, 22 (2): 377-387.

Jan, I. 2020b. Rainwater harvesting: viable solution for water security in rural and mountainous areas of Pakistan. In: Sara, S.A. (Ed.). The Kaleidoscope that is Pakistan. Islamabad Policy Research Institute (IPRI), Pakistan.

Oweis, T. and A. Hachum. 2009. Optimizing supplemental irrigation: Tradeoffs between profitability and sustainability. Agricultural Water Management, 96 (3): 511-516.

Rockström, J., L. Karlberg, S. P. Wani, J. Barron, N. Hatibu, T. Y. Oweis, A. Bruggeman, J. Farahani and Z. Qiang. 2010. Managing water in rainfed agriculture the need for a paradigm shift. Agricultural Water Management, 97 (4): 543-550.

Rosegrant, M., C. Ximing, S. Cline, and N. Nakagawa. 2002. The role of rainfed agriculture in the future of global food production. EPTD Discussion Paper 90. Environment and Production Technology Division, Washington, DC., USA: IFPRI.

Tabari, H. 2020. Climate change impact on flood and extreme precipitation increases with 
water availability. Scientific Reports. 10:13768. https://doi.org/10.1038/s41598020-70816-2.

Tiryakioğlu, M., S. Karanlik, and M. Arslan. 2015. Response of bread-wheat seedlings to waterlogging stress. Turkish Journal of Agriculture and Forestry, 39 (5): 807-816.

United Nations (UN). 2019. World population prospects: The 2019 revision. Department of Economic and Social Affairs, Population Division. New York.
United Nations Environment Program (UNEP). 1992. Agenda 21, Chapter 18. United Nations Conference on Environment and Development. http://earthwatch.unep. net/ agenda21/ 18.php.

Worldometer, 2021. Pakistan population (Live). https://www.worldometers.info/worldpopulation/ pakistan-population.

(Received: September 15, 2020; Accepted: April 13, 2021) 